\title{
Isolation, Characterization, and Quantification of Bacteria from African Sausages Sold in Nairobi County, Kenya
}

\author{
W. H. Karoki (D, D. N. Karanja, L. C. Bebora, and L. W. Njagi \\ Department of Veterinary Pathology, Microbiology and Parasitology, University of Nairobi, P.O. Box 29053-00625, Nairobi, Kenya \\ Correspondence should be addressed to W. H. Karoki; henrykaroki18@gmail.com
}

Received 10 June 2018; Revised 28 September 2018; Accepted 15 October 2018; Published 23 October 2018

Academic Editor: Amy Simonne

Copyright (C) 2018 W. H. Karoki et al. This is an open access article distributed under the Creative Commons Attribution License, which permits unrestricted use, distribution, and reproduction in any medium, provided the original work is properly cited.

\begin{abstract}
African sausages are local popular delicacies in Kenya. Demand for these sausages has resulted in this delicacy's vendors being on the increase. However, health risk posed to unsuspecting consumers of African sausages sold in informal, unhygienic make shift road-side kiosks in major cities of Kenya is largely unknown. A descriptive study was designed to isolate, characterize and quantify bacteria from African sausages sold in Nairobi County. A total of hundred (100) African sausages (62 roasted and 38 nonroasted) were conveniently collected from three meat eatery points of Westlands, Kangemi slum, and Pangani estates. Five genera of bacteria, namely, Staphylococcus spp. at 50.4\%, Bacillus spp. at 19.5\%, Streptococcus spp. 9.8\%, Proteus spp. $2.4 \%$, and E. coli spp. at 1.6\%, were isolated from 80 African sausage samples. The total aerobic bacterial count range was between $1.0-9.9 \times 10^{1}$ and $1.0-9.9 \times 10^{7} \log \mathrm{cfu} / \mathrm{g}$ with 37 samples having total aerobic bacterial count of between $1.0-9.9 \times 10^{4}$ and $1.0-9.9 \times 10^{7} \log \mathrm{cfu} / \mathrm{g}$. There was no significant difference $(\mathrm{p}>0.05)$ in distribution of isolates and total aerobic bacterial count across geographical sites studied among the roasted and nonroasted African sausages. This study has demonstrated presence of bacteria in African sausages which are potentially zoonotic to humans. Comprehensive study is needed to sample more eatery meat points in Nairobi and other areas in order to demonstrate pathogenic attributes of these isolates and establish the respective total aerobic bacterial count. There is also need to establish the sources of bacteria due to high total aerobic bacterial count determined in the current study.
\end{abstract}

\section{Introduction}

African sausages, popularly known as Kenyan sausages locally known as "Mutura" in Kikuyu dialect, is a local delicacy for low, middle income earners and beer drinkers. It is a protein rich meat snack comprising goat or cow cleaned intestines stuffed with cooked small pieces of meat and formed into long coils; sometimes blood is added. Processed African sausages are then placed in boiling water or soup for 30 to 40 minutes and then roasted over coals on outdoor grills using low to medium heat and turning frequently to dehydrate the meat and give it the sensational smoky taste. The internal temperature should be at least 160 degrees Fahrenheit [1].

Animal proteins such as meat, meat products, and even blood are regarded as high-risk perishable commodities with respect to pathogen content, natural toxins, and other possible contaminants [2]. Among the bacteria isolated from animal products in recent studies include Staphylococcus aureus, Streptococcus sp., Escherichia coli, Campylobacter jejuni, Clostridium perfringens, Shigella sp., and Salmonella sp.

Consumption of food with such microbial pathogens and toxins is estimated to result in approximately 1.5 billion episodes of diarrhea and over 3 million deaths globally each year [3]. Increase in demand for finger-licking African sausages has resulted in this delicacy's vendors being on the increase, especially in slum areas [4]. These informal businesses mostly operate in unhygienic makeshift and roadside meat points of Nairobi and major cities in Kenya, where they are unregulated and the standardized preparation of these African sausages is disregarded.

In regard to Torok et al. [5] study, food-borne disease from African sausages arises from intestinal bacteria or external contamination, which is a result of unhygienic food preparation especially if the vendor fails to adhere to hygiene practices during processing, preparation, handling, 
and/or storage; it may therefore pose serious health risk to unsuspecting consumers resulting in outbreaks of foodborne illnesses. Results of this study will help the relevant regulatory body in laying down food safety measures for the African sausages.

\section{Materials and Methods}

2.1. Study Design. A descriptive study design was employed whereby a convenience sampling of retail meat outlets from Westlands, Pangani, and Kangemi was carried out. One hundred (100) African sausages samples (38 nonroasted and 62 roasted) were collected, processed, isolated, characterized, and quantified.

2.2. Study Area. The study was carried out in Nairobi County which is one of the 47 counties of Kenya [6]. It is the smallest yet most populous county, the capital and largest city of Kenya, which has experienced one of the most rapid growths in urban centres with a population of 3,375,000 as at year 2009 census [7]. It has a total area of $696 \mathrm{~km}^{2}$ with 17 parliamentary constituencies. Nairobi is a cosmopolitan and a multicultural city.

Economically, it can be subdivided into three main categories: (1) the high end or leafy suburbs or upper-class estates, the likes of Muthaiga, Karen, Westlands, among others, (2) the Middle-class estates of Pangani, Buruburu, among others, and (3) low class estates of Mukuru, Mathare, Kangemi slums, among others [8]. Three ready-to-eat vending sites and meat eatery points of Westlands market, Kangemi market, and Pangani estate were conveniently selected on the basis of easy access, perceived sanitation, and relative hygiene levels. The number of vendors in these areas is not known; but they tend to converge around the shopping areas.

2.3. Sample Size Calculation. Prevalence of common meat contaminants in previous studies was used to determine the sample size required to detect the presence of the bacteria. An expected prevalence rate of between $7 \%$ was used to estimate the sample size in this study since similar studies [912] reported a prevalence rate of between 3 and 14\%. Using the above information, the sample size was calculated using the formula: $n=z^{2} p q / d^{2}$ where $n$ is the desired sample size, $\mathrm{Z}$ is the standard normal deviate set at $1.96, \mathrm{p}$ is the estimated prevalence, $q=1-p$, and $d$ is the degree of accuracy set at 0.05 as given by Fisher et al. [13].

2.4. Homogenate Preparation. At the laboratory, one-gram portions of the African sausages (roasted and nonroasted) were obtained aseptically from the vendors, picked separately as they are sold using sterile glass bottles, stored on ice before processing in the laboratory within 24 hours of collection, cut into small pieces on a sterile chopping board using a sterile knife, and blended (homogenized) in $4 \mathrm{ml}$ of $0.1 \%$ peptone water to obtain 1:5 initial dilution.

2.5. Bacterial Isolation and Characterization. Since the researcher suspected presence of coliforms and other fastidious organisms, the homogenates of the African sausages were streaked on general purpose enriched medium (blood agar) and selective and differential medium for members of family Enterobacteriaceae (MacConkey agar) (Oxoid Ltd. Thermo Scientific, UK) and incubated aerobically at $37^{\circ} \mathrm{C}$ for 24 hours. The isolated bacteria were identified based on colony morphology, Gram staining reaction, and biochemical characteristics using established standardized methods according to Bergey's Manual of determinative bacteriology [14].

2.6. Quantification of Total Aerobic Bacterial Count of the African Sausages. For the determination of bacterial load (total bacterial count), method given by Miles and Misra [15] was used. Serial dilutions of $10^{-1}$ to $10^{-10}$ were prepared from the African sausage homogenate stock solution that was prepared earlier. Nutrient agar plate was divided into four quadrants, and each quadrant served as one plate. Using a $25 \mu \mathrm{l}$ calibrated dropper (equivalent to $1 / 40^{\text {th }}$ of an $\mathrm{ml}$ ), one drop from each dilution tube was placed per quadrant; each dilution was done in quadruplicate.

The drop was then allowed to dry and the plate incubated aerobically at $37^{\circ} \mathrm{C}$ for 24 hours [16], after which the number of colonies that grew per drop was counted using Quebec Dark Field colony counter taking the average count for the quadruplicate drops of each dilution. The concentration of the original bacterial suspension was then calculated and expressed as colony forming units per millilitre $(\mathrm{cfu} / \mathrm{ml})$, using the formula, a $\mathrm{x} 40 \times 10^{\mathrm{y}}$, where a is the average number of colonies in the 4 drops of one dilution tube/diluted suspension, 40 is the number of drops that make one millilitre (the drop being equivalent to $1.40^{\text {th }}$ of a $\mathrm{ml}$ ), and $10^{\mathrm{y}}$ is the dilution factor of the respective dilution tube/diluted suspension. This is then multiplied by 5 , the initial dilution at homogenization stage.

2.7. Statistical Analysis. The experiment was done in triplicate. The means for the prevalence of bacterial isolates across the three geographical sites and the bacterial counts were compared by a Paired-Samples T Test. Differences were considered statistically significant when $\mathrm{P}<0.05$. Statistical analysis was conducted using the software SPSS 13.0 (SPSS, Chicago, Illinois, USA)

\section{Results}

3.1. Isolation and Characterization. Figure 1 gives results on the prevalence of isolated and characterized bacterial isolates. Five genera of bacteria (123 isolates) were isolated and characterized from 80/100 (80\%) roasted and nonroasted African sausages. They were Staphylococcus, Bacillus spp., Streptococcus spp., Proteus spp., and Escherichia coli. Staphylococci spp. were the most predominant bacteria in all the sausage samples collected with a prevalence of $50.4 \%$ (62/123), Bacillus spp. at 19.5\% (24/123), Streptococcus spp. 9.8\% (12/123), and Proteus spp. 2.4\% (3/123) while E. coli was isolated at $1.6 \%(2 / 123)$. With respect to roasted African sausages, Staphylococcus spp. accounted for $53.6 \%(15 / 28)$ of the isolates in Kangemi, 52.2\% (12/23) in Pangani, and 38.1\% $(8 / 21)$ in Westlands. Bacillus spp. organisms were isolated at 


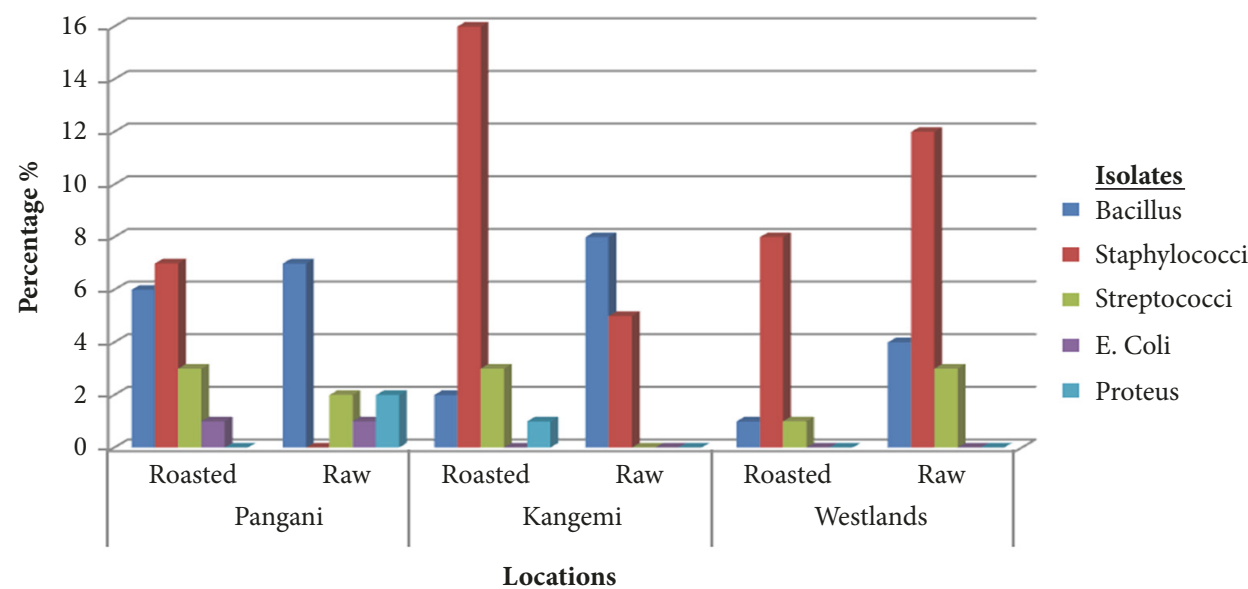

Figure 1: Prevalence of the five genera of bacteria isolated from African sausages sampled from Pangani, Kangemi, and Westlands estates, Nairobi County, Kenya: $\mathrm{n}=100$.

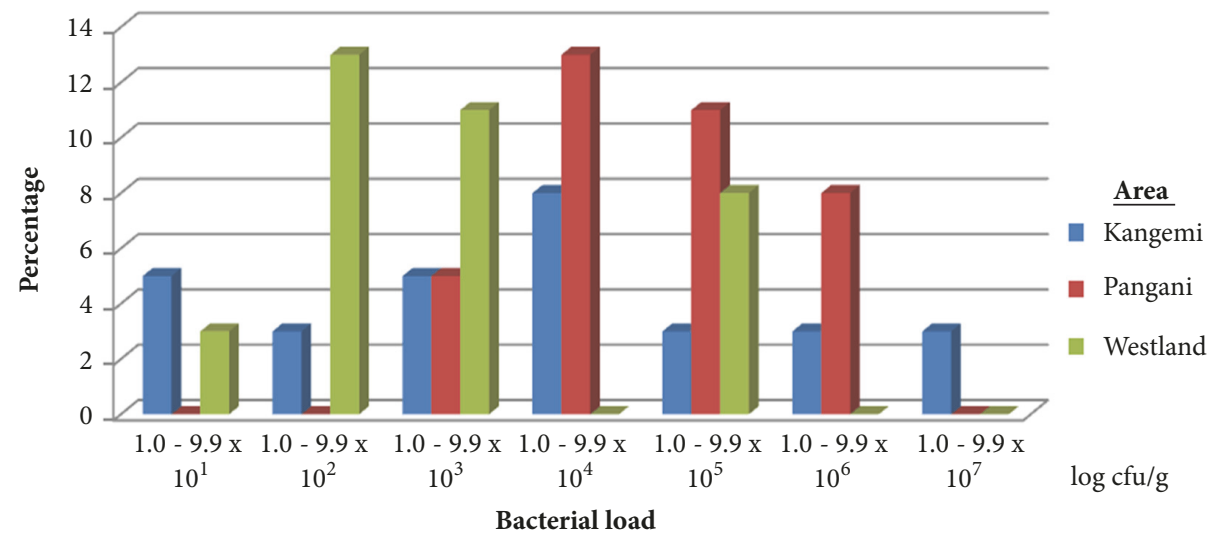

FIgURE 2: Percent total aerobic bacterial counts of the sampled roasted African sausages sold in the three study sites: $\mathrm{n}=100$.

7.1\% (2/28) in Kangemi, 26.1\% (6/23) in Pangani, and 4.8\% $(1 / 21)$ in Westlands; Streptococcus 10.7\% (3/28) in Kangemi, $13 \%(3 / 23)$ in Pangani, and $4.8 \% 3 / 21)$ in Westlands; Proteus $3.6 \%(1 / 28)$ in Kangemi and $0 \%$ both in Pangani and in Westlands; E. coli, 4.3\% (1/23) in Pangani and $0 \%$ both in Kangemi and in Westlands.

With respect to nonroasted African sausages, Staphylococcus spp. accounted for $50 \%(6 / 12)$ of the isolates in Kangemi, 45.5\% (10/22) in Pangani, and 64.7\% (11/17) in Westlands. Bacillus spp. organisms were isolated at $41.7 \%$ (5/12) in Kangemi, 31.8\% (7/22) in Pangani, and 17.6\% (3/17) in Westlands; Streptococcus spp. 0\% in Kangemi, 9.1\% (2/22) in Pangani, and 17.6\% (3/17) in Westlands; Proteus spp., 9.1\% $(2 / 22)$ in Pangani and $0 \%$ both in Kangemi and in Westlands areas; E. coli, $4.5 \%$ (1/22) in Pangani and 0\% both in Kangemi and in Westlands areas. Table 1 gives the mean distribution of bacterial isolates. There was no significant difference ( $p>0.05)$ in distribution of isolates across the geographical areas under study.

3.2. Total Aerobic Bacterial Count from Roasted African Sausage. The results are as given in Figure 2. 22/62 (35.5\%) roasted African sausage samples had a total aerobic bacterial count of between 1.0 and $9.9 \times 10^{1} \log \mathrm{cfu} / \mathrm{g}, 11 / 62(17.7 \%)$ samples had a total aerobic bacterial count of between 1.0 and $9.9 \times 10^{2} \log \mathrm{cfu} / \mathrm{g}, 12 / 62(19 \%)$ samples had a total aerobic bacterial count of between 1.0 and $9.9 \times 10^{3} \log \mathrm{cfu} / \mathrm{g}, 9 / 62$ (14.5\%) samples had a total aerobic bacterial count of between 1.0 and $9.9 \times 10^{4} \log \mathrm{cfu} / \mathrm{g}, 5 / 62(8 \%)$ samples had a total aerobic bacterial count of between 1.0 and $9.9 \times 10^{5} \mathrm{log} \mathrm{cfu} / \mathrm{g}$, 2/62 (3\%) samples had a total aerobic bacterial count of between 1.0 and $9.9 \times 10^{6} \mathrm{log} \mathrm{cfu} / \mathrm{g}$, and 1/62 (1.6\%) sample had a total aerobic bacterial count of between 1.0 and $9.9 \times 10^{7}$ $\log \mathrm{cfu} / \mathrm{g}$.

With respect to individual study sites, 10/24 (41.7\%) of samples from Kangemi, 3/19 (15.8\%) from Pangani, and 9/20 (45\%) from Westlands area had a total aerobic bacterial count of between 1.0 and $9.9 \times 10^{1} \log \mathrm{cfu} / \mathrm{g} .1 / 24$ (4.17\%) of samples from Kangemi, $3 / 19$ (15.8\%) from Pangani, and 7/20 (35\%) from Westlands area had a bacterial load of between 1.0 and $9.9 \times 10^{2} \log \mathrm{cfu} / \mathrm{g} .4 / 24$ (16.7\%) of samples from Kangemi, 7/19 (36.8\%) from Pangani, and 1/20 (5\%) from Westlands area had a bacterial load of between 1.0 and $9.9 \times 10^{3 \log } \mathrm{cfu} / \mathrm{g} .3 / 24$ (12.5\%) of samples from Kangemi, 4/19 (21\%) from Pangani, and 2/20 (10\%) from Westlands area had a bacterial load of 


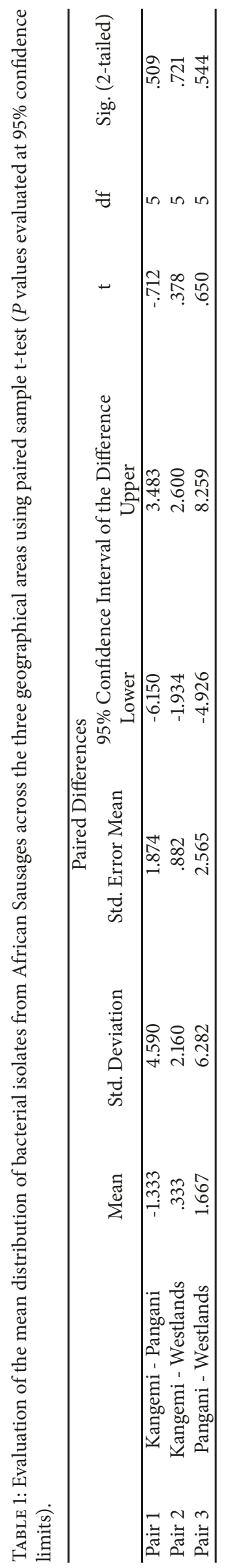




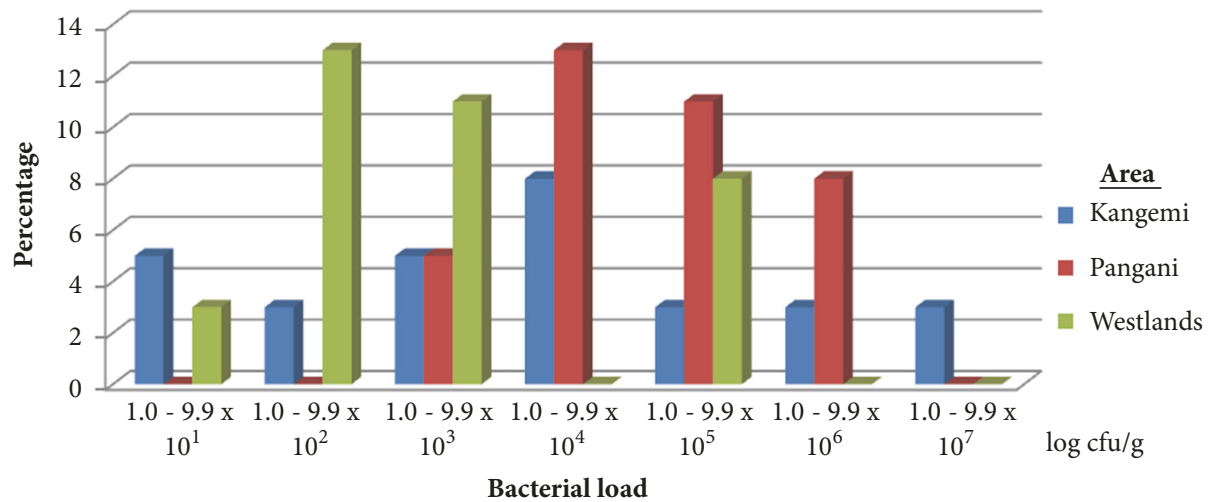

Figure 3: Percent total aerobic bacterial counts of the sampled nonroasted African sausages sold in the three study sites: $\mathrm{n}=100$.

between 1.0 and $9.9 \times 10^{4} \log \mathrm{cfu} / \mathrm{g} .3 / 24(12.5 \%)$ of samples from Kangemi, $2 / 19$ (10.5\%) from Pangani, and 0\% from Westlands area had a bacterial load of between 1.0 and 9.9 x $10^{5} \log$ cfu/g. 2/24 (8.3\%) of samples from Kangemi, 0\% from Pangani and Westlands area had a bacterial load of between 1.0 and $9.9 \times 10^{6} \log \mathrm{cfu} / \mathrm{g} .1 / 24(4.17 \%)$ of samples from Kangemi, 0\% from Pangani and Westlands area had a bacterial load of between 1.0 and $9.9 \times 10^{7} \mathrm{cfu} / \mathrm{g}$. Table 2 gives the mean total aerobic bacterial count from roasted African sausages across the three geographical areas. There was no significant difference $(\mathrm{p} \geq 0.05)$ in mean total aerobic bacterial count across the areas under study.

3.3. Total Aerobic Bacterial Count from Nonroasted African Sausages. The results are as given in Figure 3. 3/38 (7.9\%) nonroasted African sausage samples had a total aerobic bacterial count of between 1.0 and $9.9 \times 10^{1} \mathrm{log} \mathrm{cfu} / \mathrm{g}, 6 / 38$ (15.79\%) samples had a total aerobic bacterial count of between 1.0 and $9.9 \times 10^{2} \log \mathrm{cfu} / \mathrm{g}, 8 / 38$ (21\%) samples had a total aerobic bacterial count of between 1.0 and $9.9 \times 10^{3} \mathrm{log}$ cfu/g, 8/38 (21\%) samples had a total aerobic bacterial count of between 1.0 and $9.9 \times 10^{4} \log \mathrm{cfu} / \mathrm{g}, 8 / 38$ (21\%) samples had a total aerobic bacterial count of between 1.0 and $9.9 \times 10^{5} \log$ $\mathrm{cfu} / \mathrm{g}, 4 / 38(10.5 \%)$ samples had a total aerobic bacterial count of between 1.0 and $9.9 \times 10^{6} \log \mathrm{cfu} / \mathrm{g}$, and 1/38 (2.6\%) sample had a total aerobic bacterial count of between 1.0 and $9.9 \times 10^{7}$ $\log \mathrm{cfu} / \mathrm{g}$. With respect to individual study sites, $2 / 11$ (18.8\%) of samples from Kangemi, 0\% from Pangani, and 1/13 (7.7\%) from Westlands area had a total aerobic bacterial count of between 1.0 and $9.9 \times 10^{1} \log \mathrm{cfu} / \mathrm{g} .1 / 11(9 \%)$ of samples from Kangemi, 0\% from Pangani, and 5/13 (38.5\%) from Westlands area had a total aerobic bacterial count of between 1.0 and $9.9 \times 10^{2} \log \mathrm{cfu} / \mathrm{g}$. 2/11 (18\%) of samples from Kangemi, 2/14 (14.3\%) from Pangani, and 4/13 (30.8\%) from Westlands area had a total aerobic bacterial count of between 1.0 and $9.9 \times 10^{3}$ $\log \mathrm{cfu} / \mathrm{g}$. 3/11 (27.3\%) of samples from Kangemi, 5/14 (35.7\%) from Pangani, and $0 \%$ from Westlands area had a total aerobic bacterial count of between 1.0 and $9.9 \times 10^{4} \log \mathrm{cfu} / \mathrm{g}$. 1/11 (9\%) of samples from Kangemi, 4/14 (28.6\%) from Pangani, and $3 / 13(23 \%)$ from Westlands area had a total aerobic bacterial count of between 1.0 and $9.9 \times 10^{5} \log \mathrm{cfu} / \mathrm{g} .1 / 11$ (9\%) of samples from Kangemi, 3/14 (21.4)\% from Pangani, and 0\% from Westlands area had a total aerobic bacterial count of between 1.0 and $9.9 \times 10^{6} \mathrm{log} \mathrm{cfu} / \mathrm{g} .1 / 11$ (9\%) of samples from Kangemi and $0 \%$ from Pangani and Westlands area had a total aerobic bacterial count of between 1.0 and $9.9 \times 10^{7} \log \mathrm{cfu} / \mathrm{g}$. Table 3 gives the mean total aerobic bacterial count from nonroasted African sausages across the three geographical areas. There was no significant difference $(p \geq 0.05)$ in mean total aerobic bacterial count across the areas under study.

\section{Discussion}

The data obtained on isolation and characterization of bacteria in the present study where Staphylococcus spp. and Bacillus spp. were the predominant isolates concurs on some aspects with reports by Oluwafemi and Simisaye [17] and Okonko et al. [18] working on beef sausages. However, differences are noted whereby in the present study Streptococci spp., Proteus spp., and E. coli were isolated while in the latter, Enterobacter, Pseudomonas, and Klebsiella species were isolated from beef sausages and seafood, respectively.

The current study showed Staphylococcus species prevalence of $50.4 \%$. This was lower than the Staphylococcus species recovery at $58.6 \%$ from hotels, restaurants, and cafes, report by Berynestad and Granums [19]. A study by Yusuf et al. [20], on percent occurrence of bacteria isolated from the "balangu" meat product in relation to all the retail outlets, reported a lower prevalence of Staphylococcus aureus at $12.5 \%$. A study by Aycicek et al. [21] reported that processed foods were found to be more prone to Staphylococcus species contamination. This may have been attributed to contamination from aerial spores carried in the air, throat, hands, and nail of food handling persons [22].

The results of the roasted African sausages in current study contrast the findings by Orogu and Oshilim [22] who reported a higher prevalence (30\%) of Bacillus from suya meat. However, similar prevalence was obtained by a study by Matos et al. [23] working with dry smoked sausages. Presence of Bacillus contamination in some of the samples examined 


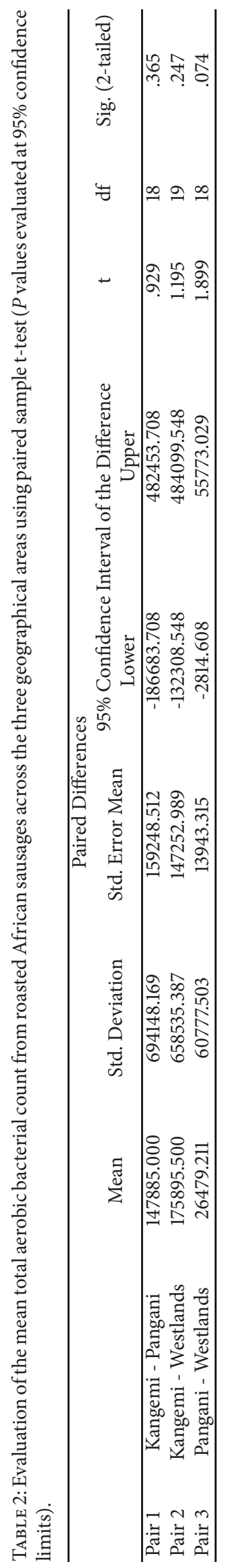




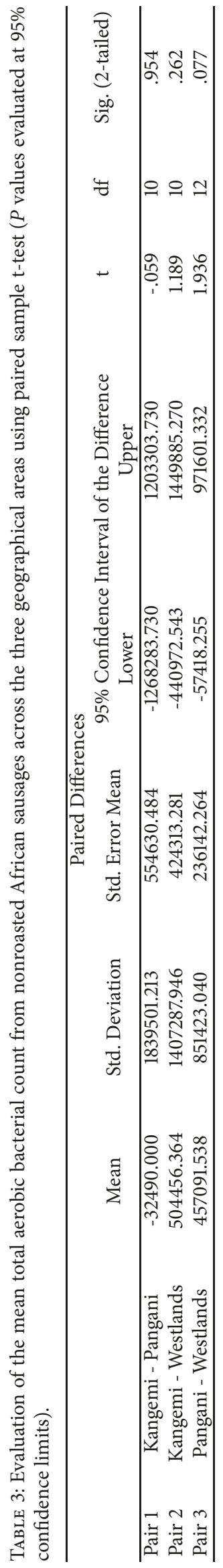


in this study might have resulted from contamination from vendor's skin or the environment.

Similar finding on the prevalence of Streptococcus spp. was reported by Onuora et al. [24] working on grilled beef. The prevalence of $E$. coli reported in present study was slightly lower than that reported by Syne et al. [25] and Onuora et al. [24]. E. coli presence in African sausages has the potential to cause diarrhea.

The incidence of $E$. coli obtained in this study is a cause for public health concern as this bacterium has been implicated in cases of gastroenteritis [26]. The presence of Proteus isolates was remarkably higher in a study by Gwinda et al. [27] from beef meat, compared to what was found in the current study. The presence of Proteus organisms in the meat samples can obviously be attributed to unhygienic food processing.

Staphylococcus spp., Bacillus spp., Streptococcus spp., and E. coli are known to produce potent enterotoxins and the ingestion of food containing these toxins can cause a sudden onset of illness within three to four hours, with nausea, vomiting, and diarrhea as the major symptoms [28]. There was no significant difference $(\mathrm{p}>0.05)$ in distribution of these organisms across the three geographical sites studied. In the present study, it was observed that there was no significant difference $(p>0.05)$ in the total aerobic bacterial count across the three geographical sites studied. Total aerobic bacterial count of between 1.0-9.9 x $10^{2}$ and $1.0 \times 9.910^{4} \log \mathrm{cfu} / \mathrm{g}$ was reported in most 54/100 (54\%) of African sausage samples.

Similar studies by Oluwafemi and Simisaye [17] reported a total aerobic bacterial count level of between $1.3 \times 10^{4}$ and $4.0 \times 10^{8} \mathrm{log} \mathrm{cfu} / \mathrm{g}$ in beef sausage samples. In related studies, Inyang et al. [29] reported a total viable count of between 3.7 $\mathrm{x} 10^{5}$ to $2.4 \times 10^{6} \log \mathrm{cfu} / \mathrm{g}$ while total viable count by Onuora et al. [24] reported a plate count of between $0.9 \times 10^{4} \mathrm{log} \mathrm{cfu} / \mathrm{g}$ and $1.5 \times 10^{4} \log \mathrm{cfu} / \mathrm{g}$.

The difference in the total bacterial counts may be attributed to the samples used, unhygienic method of transportation, handling, processing, unhygienic environment, and practices such as dirty cutting boards and knifes or utensils. Cheesbrough [28] noted that insects also contribute to contamination by mechanical transfer of microorganisms to food products since they are left uncovered and exposed to dust.

There was no significant difference $(p>0.05)$ in total aerobic bacterial count across the three geographical sites under study. This study therefore concludes that roasted and nonroasted African sausages sold in meat outlets in Nairobi County are contaminated with Staphylococcus, Bacillus, Streptococcus, Proteus, and E. coli organisms and poses food safety risks to the consumers. The presence of these organisms in ready-to-eat African sausages is a pointer that these African sausages were either processed under poor hygienic and sanitary conditions and insufficient processing or could have been from the animal intestines. Food safety enforcement authority therefore need to scale up inspection of establishments where African sausage vendors are.

\section{Data Availability}

The data used to support the findings of this study are available from the corresponding author upon request.

\section{Conflicts of Interest}

The authors declare that they have no conflicts of interest.

\section{References}

[1] M. Wiens, Kenyan Food Overview: 20 of Kenya's Best Dishes, 2011, http://migrationology.com/2011/06/kenyan-food-overview20-of-kenyas-best/dishes/.

[2] A. H. M. Yousuf, M. K. Ahmed, S. Yeasmin, N. Ahsan, M. M. Rahman, and M. M. Islam, "Prevalence of microbial load in shrimp, Penaeus monodon and prawn, Macrobrachium rosenbergii from Bangladesh," World Journal of Agricultural Science, vol. 4, pp. 852-855, 2008.

[3] World Health Organization, Foodborne Hazards in Basic Food Safety for Health Workers, 2007, http://www.who.int/foodsafety/ publications/capacity/en/2.pdf.

[4] O. L. Musa and T. M. Okande, "Effect of health education intervention or food safety practice among food vendors in ilorin," Journal of Medicine, vol. 5, pp. 120-124, 2002.

[5] T. J. Torok, R. V. Tanze, R. P. Wise, J. R. Livengood, R. Sokolow, and S. Manvans, "A large community outbreak of salmonellosis caused by intentional contamination of restaurant salad bars," Journal of the American Medical Association, vol. 278, no. 8, pp. 389-395, 1997.

[6] Nairobi City County, "Maps". Retrieved from: http://www .nairobi.go.ke/home/maps/, 2017.

[7] Kenya Population and Housing Census (KPHC), "National data archive," http://statistics.knbs.or.ke/nada/index.php/catalog/55/ study-description, 2009.

[8] Nairobi Mitaa, “A review of hoods in Nairobi”. Retrieved from: http://mitaayanairobi.blogspot.co.ke/2011? $\mathrm{m}=1,2011$.

[9] J. Miyoko, S. G. Dilma, A. R. Christiane et al., "Occurrence of Salmonella spp and Escherichia coli O157:H7 in raw meat marketed in São Paulo city, Brazil, and evaluation of its cold tolerance in ground beef," Revista do Instituto Adolfo Lutz, vol. 63, no. 2, pp. 238-242, 2004.

[10] C. A. Magwira, B. A. Gashe, and E. K. Collison, "Prevalence and antibiotic resistance profiles of Escherichia coli O157:H7 in beef products from retail outlets in Gaborone, Botswana," Journal of Food Protection, vol. 68, no. 2, pp. 403-406, 2005.

[11] J. S. Weese, B. P. Avery, J. Rousseau, and R. J. Reid-Smith, "Detection and enumeration of Clostridium difficile spores in retail beef and pork," Applied and Environmental Microbiology, vol. 75, no. 15, pp. 5009-5011, 2009.

[12] R. M. Kabwanga, M. M. Kakubua, C. K. Mukeng et al., "Bacteriological assessment of smoked game meat in Lubumbashi, D.R.C," Biotechnologie, Agronomie, Société et Environnement, vol. 17, no. 3, pp. 441-449, 2013.

[13] A. A. Fisher, J. E. Laing, J. E. Stoeckel, and J. W. Townsend, Handbook for Family Planning Operations Research Design, Population Council, New York, NY, USA, 2nd edition, 1991, https://www.popcouncil.org/.

[14] J. G. Holt, N. R. Kreig, P. H. A. Sneath, and J. T. Staley, Bergey's Manual of Determinative Bacteriology, The William and Wilkins Co., Baltimore, Md, USA, 9th edition, 1994. 
[15] A. A. Miles and S. S. Misra, "The estimation of the bactericidal power of the blood," Journal of Hygiene, vol. 38, no. 6, pp. 732$749,1938$.

[16] B. Jersěk, Microbiological Examination of Food, University of Ljubljana, 2017.

[17] F. Oluwafemi and M. T. Simisaye, "Extent of microbial contamination of sausages sold in two Nigerian cities," in Proceedings of the Book of Abstract of the 29th Annual Conference \& General Meeting (Abeokuta 2005) on Microbes as Agents of Sustainable Development, Organized by Nigerian Society for Microbiology (NSM), p. 28, University of Agriculture, Abeokuta, Nigeria, 2005.

[18] I. O. Okonko, E. Donbraye, and S. O. I. Babatunde, "Microbiological quality seafood processors and water used in two different sea processing plants in Nigeria," Electronic Journal of Environmental, Agricultural and Food Chemistry, vol. 8, no. 8, pp. 621-629, 2009.

[19] M. S. Brynestad and P. E. Granum, "Clostridium perfringens and foodborne infections," International Journal of Food Microbiology, vol. 74, no. 3, pp. 195-202, 2002.

[20] M. A. Yusuf, T. H. A. T. Abdul Hamid, and I. Hussain, "Isolation and Identification of Bacteria Associated with Balangu (Roasted Meat Product) Sold in Bauchi. Nigeria," Journal of Pharmacy, vol. 2, no. 6, pp. 38-48, 2012.

[21] H. Aycicek, S. Cakiroglu, and T. H. Stevenson, "Incidence of Staphylococcus aureus in ready-to-eat meals from military cafeterias in Ankara, Turkey," Food Control, vol. 16, no. 6, pp. 531-534, 2005.

[22] M. Hatakka, K. J. Björkroth, K. Asplund, N. Mäki-Petäys, and H. J. Korkeala, "Genotypes and enterotoxicity of Staphylococcus aureus isolated from the hands and nasal cavities of flightcatering employees," Journal of Food Protection, vol. 63, no. 11, pp. 1487-1491, 2000.

[23] J. S. T. Matos, B. B. Jensen, S. F. H. A. Barreto, and O. Hojberg, "Spoilage and pathogenic bacteria isolated from two types of portuguese dry smoked sausages after shelf-life period in modified atmosphere Package," Journal of Food, vol. 5, no. 3, pp. 165-174, 2006.

[24] S. Onuorah, I. Obika, F. Odibo, and M. Orji, "An Assessment of the Bacteriological Quality of Tsire-Suya (Grilled Beef) sold in Awka, Nigeria," American Journal of Life Sciences Researches, vol. 3, no. 4, pp. 287-292, 2015.

[25] S. M. Syne, A. Ramsubhag, and A. A. Adesiyun, "Microbiological hazard analysis of ready-to-eat meats processed at a food plant in Trinidad, West Indies," Infection Ecology \& Epidemiology, vol. 3, no. 1, Article ID 20450, 2013.

[26] W. A. Volk, Essential of Medical Microbiology, J. B. Lippincott Company, Philadelphia, Pa, USA, 1982.

[27] M. Gwida, H. Hotzel, L. Geue, and H. Tomaso, "Occurrence of Enterobacteriaceae in Raw Meat and in Human Samples from Egyptian Retail Sellers," International Scholarly Research Notices, vol. 2014, Article ID 565671, 6 pages, 2014.

[28] M. Cheesbrough, District Laboratory Practice in Tropical Countries, Cambridge University Press, Cambridge, UK, 2nd edition, 2006.

[29] C. U. Inyang, A. M. Igyor, and E. N. Uma, “" Bacterial Quality of a smoked Meat Product (Suya)," Nigerian Food Journal, vol. 23, no. 1, pp. 239-242, 2006. 


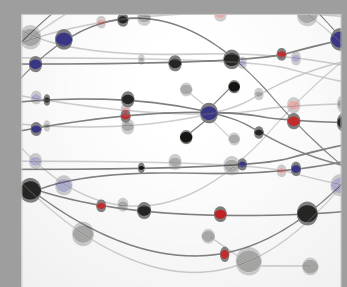

The Scientific World Journal
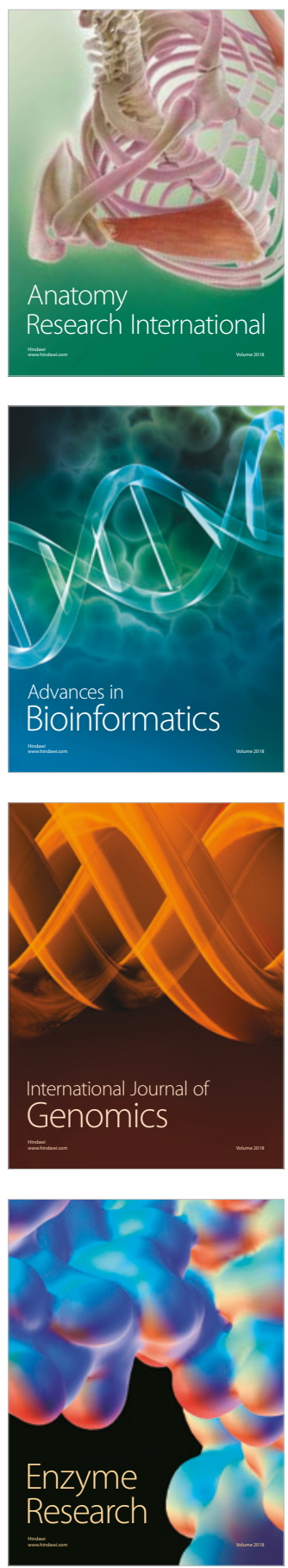
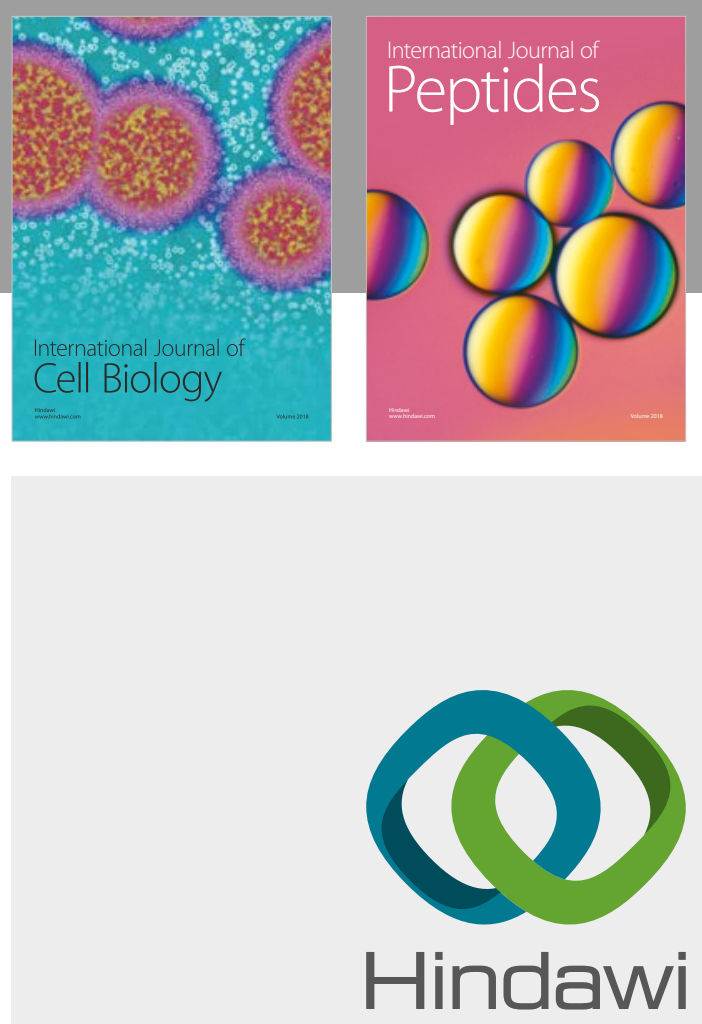

Submit your manuscripts at

www.hindawi.com
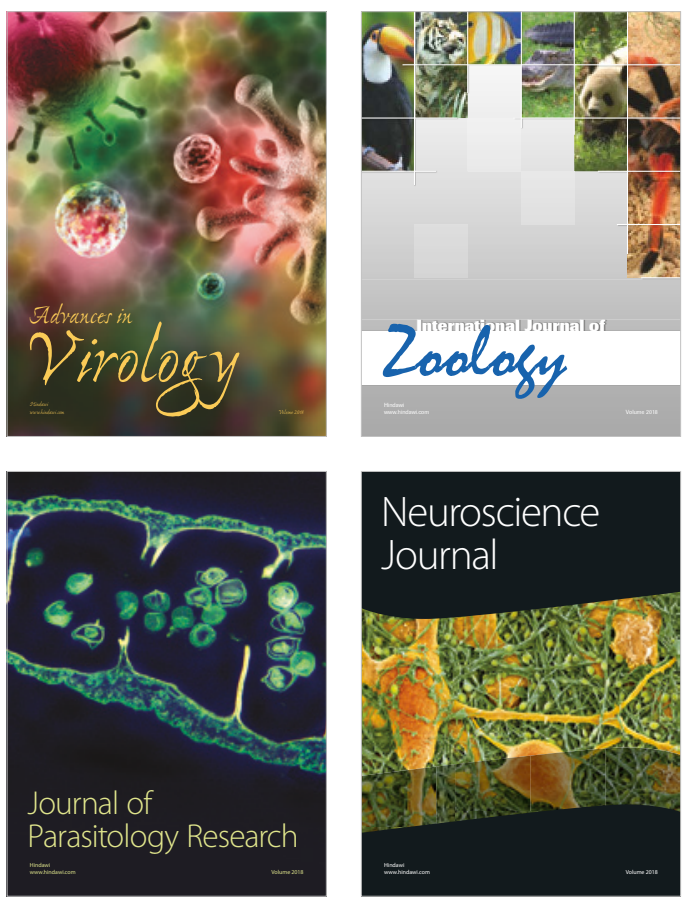
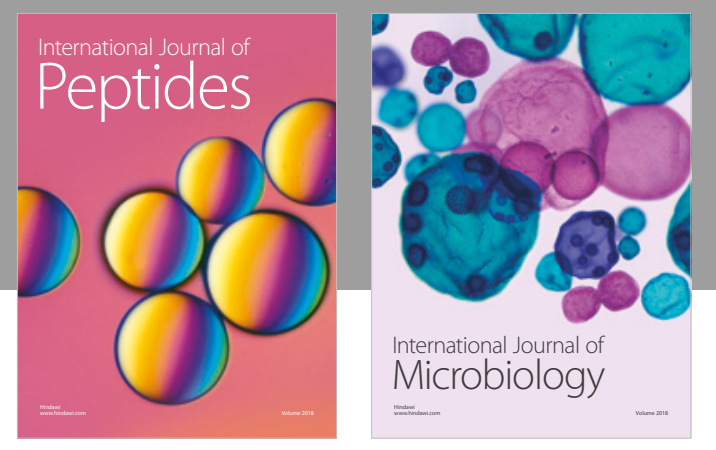

nternational Journal of Microbiology
Journal of
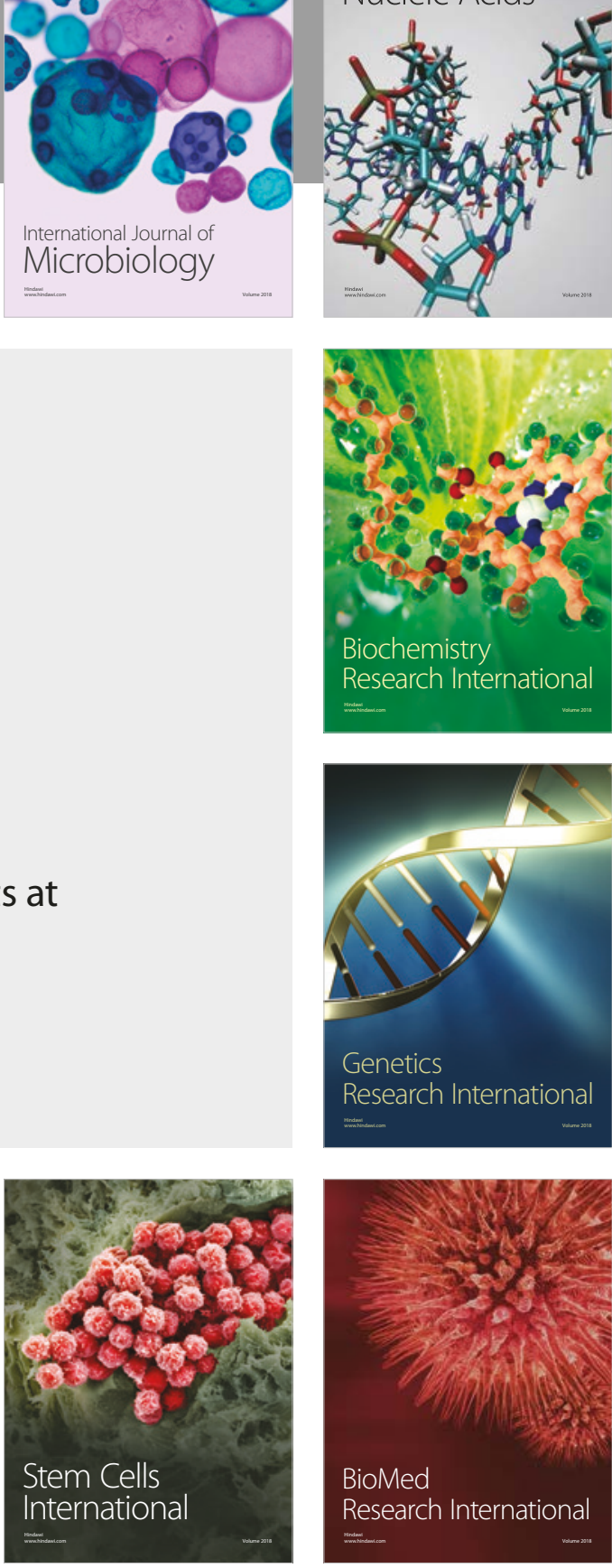
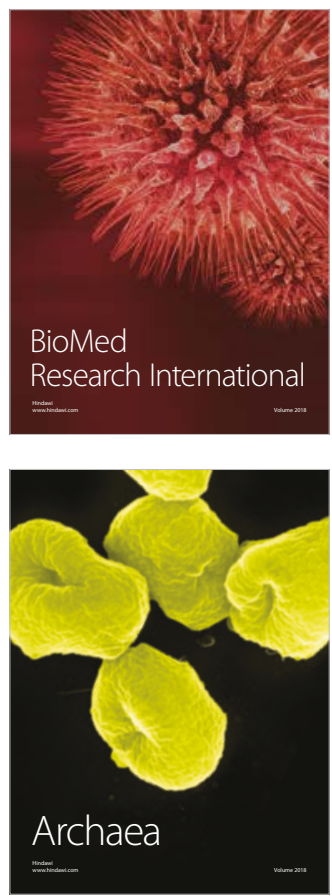